\title{
INSTRUÇÃO ISLÂMICA NA SENEGÂMBIA E PRÁTICAS DE MUÇULMANOS AFRICANOS EM PORTUGAL: UMA ABORDAGEM ATLÂNTICA (SÉCULOS XVI E XVII)
}

Islamic instruction in Senegambia and practices of African Muslims in Portugal: an Atlantic approach (16th and 17 th centuries)

Instrucción islámica en Senegambia y las prácticas de los musulmanes africanos en Portugal: un enfoque del Atlántico (siglos XVI y XVII)

\section{THIAGO HENRIQUE MOTA}

http://dx.doi.org/10.1590/\$2178-14942017000100003

Thiago Henrique Mota é mestre em História Social pela Universidade Federal Fluminense e doutorando em História em regime de cotutela entre a Universidade Federal de Minas Gerais e a Universidade de Lisboa, com bolsa oferecida pela FAPEMIG. Foi professor temporário na Universidade Federal de Viçosa (2012-2013) e pesquisador visitante na Universidade Eduardo Mondlane (2014-2014), em Moçambique. É investigador no Centro de História da Universidade de Lisboa (2016). Esta pesquisa contou com recursos da Cátedra Jaime Cortesão, à qual o pesquisador remete seus agradecimentos. (thiago. mota@ymail.com).

Artigo recebido em 11 de julho de 2016 e aprovado para publicação em 2 de fevereiro de 2017. 


\section{RESUMO}

Práticas islâmicas de africanos escravizados em Portugal no século XVI são analisadas à luz da metodologia atlântica, buscando-se compreendê-las em relação às instituições muçulmanas na região dos rios Senegal e Gâmbia. Parte-se desta perspectiva para estudar culturas africanas na diáspora identificando elementos africanos em Portugal; retornando à África, são relacionados às sociedades de origem; voltando a Portugal, os dados obtidos são confrontados. As fontes da pesquisa são memoriais de viajantes europeus, cartas de jesuítas e processos inquisitoriais. Argumenta-se que as práticas islâmicas em Portugal expõem continuidades de experiências africanas, evidenciando o papel do Islã nas sociedades da Senegâmbia.

PAlaVRAS-CHAVE: Islã, Senegâmbia, Wolof, metodologia atlântica, Portugal, Inquisição.

\section{Abstract}

Islamic practices of enslaved Africans in 16th century Portugal are discussed through an Atlantic methodology, high-lighting relations between Islam in Senegal and Gambia Rivers' region and Muslim African religiosities in Portugal. This approach aims to analyze African cultures in a diaspora context. Then, Muslim African features are discussed in Portugal; back to Africa, those features are connected to local institutions; back again to Portugal, both data are compared. The sources analyzed are European travelers' accounts, jesuits' letters and inquisitorial records. Muslim beliefs in Portugal are linked to their African experiences, what emphasizes the role of Islam in Senegambian societies.

KeYwORDS: Islam, Senegambia, Wolof, Atlantic methodology, Portugal, Inquisition.

\section{RESUMEN}

Prácticas islámicas de esclavos africanos en Portugal en el siglo XVI se analizan a la luz de la metodología del Atlántico, buscando entender en relación con las instituciones musulmanas en la región de los ríos Senegal y Gambia. Se inicia esta perspectiva para estudiar las culturas africanas en la diáspora que identifican elementos africanos en Portugal; volver a África, que están relacionados con las sociedades de origen; regresar a Portugal, se comparan los datos obtenidos. Las fuentes de investigación son monumentos conmemorativos de los viajeros europeos, cartas jesuitas y procesos inquisitoriales. Se argumenta que las prácticas islámicas en Portugal exponen continuidades de las experiencias africanas, destacando el papel del Islam en las sociedades de Senegambia.

Palabras ClaVe: Islam, Senegambia, Wolof, metodología atlántica, Portugal, Inquisición. 


\section{INTRODUÇÃO}

$\mathrm{N}$

este artigo, objetivamos compreender o desenvolvimento da instrução religiosa muçulmana na bacia dos rios Senegal e Gâmbia, a Senegâmbia, nos séculos XVI e XVII, destacando sua continuidade no Mundo Atlântico. Analisamos documentos produzidos a partir de experiências europeias na África e provenientes da presença africana em Portugal. No primeiro caso, destacam-se fontes narrativas, como memoriais, cartas e tratados elaborados por comerciantes, burocratas e missionários europeus. No segundo, analisamos processos inquisitoriais contra homens jalofos ${ }^{1}$ acusados de prática islâmica em Portugal. Na documentação narrativa, povos Jalofo, Mandinga e Fula aparecem constantemente vinculados ao Islã. Contudo, na Inquisição portuguesa, somente jalofos estão presentes: do total de 288 processos contra muçulmanos em Portugal com origem identificada, no século XVI, 15 correspondem a este etnônimo, o único referente a povos da Senegâmbia (Ribas, 2005).

As fontes narrativas trazem informações decorrentes de vivências e oralidades, europeias e africanas, que exprimem concepções tanto locais quanto externas sobre os eventos reportados (Horta, 2011). Contudo, elas são filtradas por interesses europeus, que selecionam, substituem e eliminam informações nos seus textos com vistas ao papel a ser desempenhado pelas narrativas no processo de produção, circulação e consumo das informações (Maingueneau, 1997). Complementando este acervo, o recurso a fontes judiciais para acessar vozes e agências de indivíduos subalternizados tem sido um campo de atuação crescente dos historiadores (Ginzburg, 1991; Faria, 2016). Os processos inquisitoriais enquadram-se nesta categoria. Apesar da violência e desigualdade das relações estabelecidas diante do Tribunal do Santo Ofício, a documentação proveniente destes inquéritos traz dados ausentes em outras fontes, que contribuem para o entendimento de questões que superam os incidentes judiciais em pauta. Revelam práticas, memórias e experiências anteriores à escravidão. Ao lidar com fontes judiciais, interessam-nos as memórias, referentes às experiências muçulmanas africanas, e as práticas continuadas em Portugal.

Os estudos sobre a presença africana em Portugal são extensos. Os primeiros trabalhos portugueses sobre o tema, em contexto abolicionista, buscavam evidenciar a universalidade da escravidão e defender Portugal diante da acusação de ser responsável pela instituição 
do tráfico de pessoas escravizadas. No Estado Novo português (1933-1974), desenvolveu-se uma historiografia ocupada em legitimar as atitudes portuguesas, limitando a pesquisa aos interesses do Estado. As renovações temáticas e metodológicas que impactaram o campo da História em geral, a partir das décadas finais do século XX, influenciaram os estudos sobre africanos em Portugal, destacando contribuições no campo das artes, religiosidades e cultura, além de evidenciar o peso demográfico desta população (Saunders, 1982; Tinhorão, 1988; Fonseca, 2016).

Na Inquisição portuguesa, os muçulmanos da Senegâmbia aparecem apenas em terras lusitanas. As visitações do Tribunal do Santo Ofício em Cabo Verde, São Tomé e Príncipe e na Guiné, entre 1536 e 1821, focaram nos desvios de fé de portugueses e afro-portugueses, com destaque para a perseguição aos judeus e cristãos novos (judeus convertidos ao catolicismo e seus descendentes), e aos aderentes às religiosidades locais (Silva, 2002). Nenhum processo foi movido contra muçulmanos. Já na Inquisição europeia e na América, os africanos foram tema de várias pesquisas, que se inserem na renovação dos estudos a partir de fontes inquisitoriais.

Neste processo metodológico, Carlo Ginzburg (1991) aponta a influência da antropologia sobre a história e debate o modo como questões antes tratadas de forma residual, como feitiçaria e manifestações da cultura popular, ganharam destaque frente aos estudos acerca do funcionamento dos tribunais. Nesta nova configuração, os processos judiciais têm alcançado dimensões significativas na produção historiográfica, superando a perseguição como objeto de estudo em favor dos delitos reportados. Recente artigo de Alexandre Marcussi (2016) evidencia as possibilidades e limites do uso desta documentação, sobretudo ao lidar com tema central à estrutura social do Antigo Regime português: a ideologia da escravidão do ponto de vista de um pregador africano. Marcussi destaca o contexto de produção dessas fontes, marcado por esquemas de pensamento alheios aos réus, que exige cuidados dos pesquisadores.

Daniela Calainho (2008) estudou processos contra africanos acusados de feitiçaria em Portugal entre os séculos XVI e XVIII. Entre suas conclusões, destaca o caráter atlântico da religiosidade dos escravizados, resultante da circulação entre África, Brasil e Portugal. Vanicléia Santos (2012) analisou o modo como africanos, afro-portugueses e afro-brasileiros incorporaram novas práticas a partir de velhos significados. Através de processos inquisitoriais, demonstrou como as bolsas de mandinga excederam o grupo étnico Mandinga, resultando de circulação e ressignificação cultural através do Atlântico. No trato específico da população jalofa, destacam-se os estudos de James Sweet (2007) e Rogério Ribas (2005): o primeiro interessado nas práticas culturais de africanos no mundo afro-português; o segundo dedicado a estudar a presença islâmica no Portugal quinhentista. Ambos os autores consideram 
a presença jalofa na Inquisição portuguesa como resultado de conflitos travados na África, reconhecendo as transformações na política africana como condição para a inserção daqueles indivíduos em Portugal.

No quadro historiográfico, esta pesquisa se posiciona nos debates sobre rupturas ou continuidades culturais, no contexto do tráfico de pessoas escravizadas. As teses crioulistas forjadas na década de 1970, que afirmavam que as culturas africanas não haviam sobrevivido ao tráfico atlântico e, portanto, que as culturas negras nas Américas resultaram de novos arranjos, foram largamente criticadas a partir dos anos 1990. Hoje, teórica e empiricamente refinado, este debate apresenta duas posições fundamentais: o deslocamento da crioulização para a África e a defesa da continuidade cultural africana, entre aquele continente e o Mundo Atlântico.

Um dos expoentes do deslocamento da crioulização para África, John Thornton (2004: 49) defende que "as influências europeias na vida africana, como o cristianismo, o dialeto crioulo e a moda, com frequência já existiam antes na África e só mais tarde transferiram-se para as Américas". Portanto, as sínteses americanas seriam, na verdade, sínteses produzidas no continente africano. Por outro lado, James Sweet - contrapondo as conclusões de Thornton acerca do cristianismo no Congo - argumenta que tal compreensão parte de suposta ênfase no caráter superior da religião cristã, que teria levado ao despojamento da espiritualidade congolesa. Para este autor, a ideia de crioulização como nascimento de novas culturas não é suportada pela documentação, que evidencia continuidades africanas no Mundo Atlântico.

Buscamos trazer alguma contribuição a este debate a partir de um tema pouco visitado pela historiografia sobre culturas africanas: o Islã. Sylviane Diouf ([1998] 2013) e Michael Gomez (2005) constataram a importância do Islã na África Ocidental na época do tráfico e reconhecem sua continuidade na América. Por diferentes caminhos, os autores apontaram a presença islâmica africana na América, suas formas institucionais de continuidade e seu impacto na estruturação de comunidades muçulmanas americanas a partir do século XVII. João Reis (2003) abordou os muçulmanos atuantes na Bahia no início do século XIX, no contexto da Revolta dos Malês de 1835, destacando as experiências anteriores como centrais na organização do levante. Nossa pesquisa busca contribuir com este campo, discutindo aspectos do Islã na Senegâmbia a partir de dados da presença de muçulmanos jalofos em Portugal.

Para tanto, utilizamos uma metodologia de abordagem atlântica: apontamos elementos das culturas negras na escravidão atlântica; retornamos à África para compreendê-los no contexto social de origem dos indivíduos; voltamos à escravidão atlântica para comparar os dados obtidos neste processo. Tal procedimento busca historicizar a cultura a partir de conexões transcontinentais (Bailyn, 1996; Gilroy, 2001; Chambers, 2008). Argumentamos que 
a instrução islâmica na Senegâmbia foi fundamental para a continuidade do Islã entre a população jalofa em Portugal. Ao confrontar fontes narrativas e inquisitoriais, notamos que os dados procedentes das memórias e práticas mobilizadas pelos processados subsidiam 0 entendimento da instrução religiosa descrita na África e ratificam seus impactos na atribuição de sentido às experiências dos muçulmanos jalofos na diáspora atlântica.

\section{ISLÃ NA SENEGÂMBIA}

A presença islâmica no Senegal remonta ao século XI, quando o movimento dos Almorávidas partiu do vale deste rio rumo ao Magrebe. A instalação do Islã no Mali, a partir do século XIII, e as tradições orais familiares do estado² do Caior, que ligam as famílias mais antigas a linhagens marabúticas, e do Salum, que descrevem a presença de um bexerim ao lado do conquistador Mbegan Nduur, no final do século XV e início do XVI, atestam a antiguidade desta presença (Boulègue, 2013: 89-91). Marabutos e bexerins são os personagens mais proeminentes na documentação europeia sobre o Islã devido à função de divulgação religiosa que exerciam. Não obstante a expressiva presença de pregadores muçulmanos na região, autores como Jean Boulègue e Nehemia Levtzion consideram a islamização na Senegâmbia, no período em tela, um fenômeno superficial, ligado à conversão comunitária, em detrimento de individual.

Boulègue, amparado nas narrativas de Valentim Fernandes e Alvise de Cadamosto referentes ao século XV e início do XVI, afirma que a islamização esteve vinculada sobretudo às elites com as quais comerciantes muçulmanos estiveram em contato. Ao analisar práticas culturais jalofas, Boulègue destaca a continuidade de aspectos culturais ligados às religiosidades locais, em detrimento de paradigmas islâmicos. Tal interpretação é construída na esteira da crítica feita por reformadores religiosos magrebinos ao Islã praticado no sul do Saara. Ao citar a descrição do governante do Songai, Sonni Ali, feita pelo reformador magrebino Al-Maghili (1425-1505), que criticava a simultaneidade entre Islã e crenças locais, Boulègue (2013: 96) aplica estes termos aos governantes jalofos: "a Senegâmbia terá seus reformadores, na linha de Al-Maghili, nos séculos XVII, XVIII e XIX".

Tal interpretação mobiliza o conceito de conversão comunitária em detrimento de individual, conforme elaborado por Nehemia Levtzion. Segundo este, o Islã foi adotado pelas sociedades africanas sem implicar modificação da identidade cultural e, portanto, sem rupturas com tradições, costumes e crenças locais. Por este processo, a população passaria a sofrer influência islâmica, que tomaria longo tempo para superar a religião anterior. Este intervalo temporal é compreendido como continuidade, em detrimento de ruptura: desde a aceitação nominal do Islã até o engajamento popular em seus aspectos fundamentais. Partindo deste 
modelo, Boulègue acredita que, embora o Islã fosse uma realidade coletiva, seu desenvolvimento ainda se encontrava no início.

Tal interpretação traz dois elementos: 1. a comparação entre diferentes culturas que aderiram ao Islã, hierarquizando-as como expresso nas figuras e opiniões de reformadores estrangeiros; 2 . a crença num caráter de homogeneidade cultural a partir da adesão ao Islã como processo progressivo. Concordamos com a tese da islamização como um processo em curso, no século XVI. Contudo, a busca por um complexo cultural referenciado a partir de outras regiões ou a adequação entre realidade e uma definição sobre o que é o Is/ã mostra-se perspectiva inadequada à análise da religiosidade muçulmana jalofa. Seguiremos a proposta de Clifford Geertz (2004: 16) ao afirmar que, nos estudos das religiões, o problema não é defini-las, mas encontrá-las. Portanto, buscamos compreender a fé muçulmana entre os jalofos para além das alegorias culturais. Partimos da autoconcepção islâmica associada à aceitação da unidade de Deus e à crença profética em Maomé, como indicativo individual da islamização; e a existência de instituições de instrução religiosa, formais ou informais, como expressão social deste processo. Para tanto, a análise do Islã na Senegâmbia é enriquecida pelo confronto entre informações procedentes da região e outras oriundas da escravidão atlântica.

\section{MuÇUlmanos JALOFOS EM PORTUGAL: TRAJETÓRIAS E PROJETOS}

$\mathrm{F}$ rancisco Jalofo nasceu entre 1527 e 1528, na Senegâmbia, em meio aos conflitos políticos decorrentes da fragmentação da confederação Jolof, diante da busca por autonomia das províncias costeiras. 0 esfacelamento da confederação foi seguido pela expansão territorial de povos Fula, em busca de melhores pastagens para seus rebanhos num contexto em que o couro despontava como importante commodity. Os conflitos desencadearam processos de escravização, alimentando o incipiente mercado atlântico de tráfico de pessoas, através do qual os jalofos foram compulsoriamente inseridos em Portugal. Devido à crença muçulmana que professavam, muitos foram perseguidos pela Inquisição. Nos processos, emergem dados sobre saberes religiosos prévios e relações estabelecidas com outros muçulmanos, em Portugal. Descrevendo sua trajetória aos inquisidores, Francisco contou que "havia cinco ou seis anos que cativaram a ele e a outra muita gente de sua terra" e

levaram ao castelo d'Arguim onde o venderam ao capitão João Sardinha / onde o [deixou?] um mês e meio pouco mais ou menos e que de lá se vieram a esta cidade onde o [trouxe?] consigo. E dado que chegaram a esta cidade que havia cinco anos e meio pouco mais ou menos o levaram à Casa da Índia com outros negros e que dali o levou seu senhor Bernaldim Estevam não sabe se comprado (...). ${ }^{3}$ 
A feitoria de Arguim4, estabelecida em 1448 num arquipélago próximo à costa da Mauritânia, foi o principal entreposto escravista atlântico no século XV e no início do XVI. Na primeira metade do século XVI, a partir de 1510, cerca de $90 \%$ dos escravizados desembarcados em Lisboa eram provenientes dos portos de Arguim e Cabo Verde. Entre 1535-1540, estima-se que tenham chegado anualmente à Casa da Mina e da Índia, em Lisboa, cerca de 1.500 escravizados oriundos de Arguim (Mendes, 2004). Entre os jalofos réus na Inquisição, muitos passaram pelo arquipélago mauritano: em 1553, Antônio Fernandes, "negro jalofo", informou aos inquisidores que "havia dois anos mais ou menos que veio a Portugal e que 0 trouxeram de Arguim e que em Arguim o batizaram [derramando]-Ihe água na cabeça". ${ }^{5} 0$ mesmo aconteceu com "Pedro preto Jalofo de nação", que afirmou ao inquisidor, em 1566, que "era cristão e o batizaram em Arguim e que isto havia um ano" . ${ }^{6}$ Francisco Jalofo da vila de Setúbal, processado entre 1554 e 1555, também havia passado por Arguim, onde recitava orações e praticava jejuns "da dita seita de Mafamede". ${ }^{7}$

Inseridos no tráfico atlântico, estes homens passaram a construir novas relações sociais no exílio, organizadas a partir de uma pluralidade de identidades, como pertencimento religioso, condição de cativo e região de procedência, conjugadas de diferentes maneiras. 0 objetivo comum de atingir o norte da África e desvencilhar-se das interdições impostas pelo contexto português mobilizava vários indivíduos. No processo de Francisco Jalofo, morador de Lisboa, que aconteceu entre 1553 e 1554, foi desbaratada pelos inquisidores uma grande conspiração de fuga, formada por homens jalofos, sereres, "mouros brancos" e suas mulheres. Pressionado pelo inquisidor, Francisco denunciou vários de seus companheiros:

Um mourisco preto jalofo que se veio tornar cristão e não lhe sabe o nome de cristão, e que em sua terra se chamava Hibraim, e anda a ganhar e é forro (...) e tem por mulher uma negra cativa (...) e que este mourisco, lhe disseram outros mouros jalofos, se queria ir para sua terra de mouros com outros mouros brancos e com suas mulheres, assim tornavam [lá a ser] mouros. E que um negro jalofo que se chama Bastiam, o qual é cativo de um homem manco que anda num cavalo (...), Ihe disse que o dito mouro jalofo se queria ir para terra de mouros com ele Bastiam dizendo também a ele [?] se queria ir com eles. E que também outro negro barbacim, que se chamava Gaspar (...), também Ihe disse que se queria ir com o dito negro jalofo e outros para terra de mouros. E que também um negro barbacim, que se chama Pedro (...), também disse que se queria ir para terra de mouros com duas mulheres negras de barbacim (...). E que também um Domingos jalofo (...) lhe disse que também queria fugir para terra de mouros e que este Domingos sabe ler e é grande mouro e que estes todos queriam ir em companhia. ${ }^{8}$

Francisco refere-se a Hibraim pelo nome islâmico, cuja identidade remete às vivências anteriores à escravidão atlântica, indicando a manutenção desta identidade em Portugal, 
ainda que se tratasse de um homem batizado - condição para acesso à alforria e ao estatuto de mourisco, ou seja, muçulmano convertido ao catolicismo. Além dos sobreditos personagens, havia outro homem jalofo também chamado Bastiam, "o qual é um homem branco da barba", que também desejava ir ao norte da África. A liderança religiosa era desempenhada por Domingos, que "sabe ler e é grande mouro e the disse que a lei de Mafamede era boa": um reconhecido marabuto. Contudo, alguns membros do projeto não professavam a fé islâmica. A religião não era o único elemento a dar sustentação à fuga: antes, a própria perspectiva de desvencilhar-se da escravidão tomou importante papel, mediada por relações africanas. Segundo Francisco, Gaspar e Pedro "que são barbacim, não Ihe disseram mais senão que se queriam ir pra terra de mouros como dito e que nunca estes dois lhe falaram na seita do Mafamede". ${ }^{9}$

0 grupo que desejava fugir "em companhia" era formado por homens e mulheres, negros e brancos, muçulmanos e não-muçulmanos, cativos e forros. Esta associação indica que as organizações sociais não estavam sujeitas apenas a arranjos de fundo étnico ou religioso, como as nações ou as confrarias, mas poderiam surgir de demandas específicas cuja causa tocava os interessados que compartilhavam um estatuto subalterno. Além disso, as classificações jalofo e barbacim remetem a identidades políticas e linguísticas africanas, a última aplicada à população de Sine e Salum, formada por indivíduos de língua e etnia Serere. Em Portugal, barbacim era o designativo aplicado ao Serere que, no idioma jalofo, corresponde a buur ba Siin, o governante de Sine, e aplica-se àqueles sujeitos a este potentado (Boulègue, 2013: 23-27). A documentação, portanto, explicita identidades forjadas a partir de relações políticas anteriores e manejadas no contexto da escravidão atlântica.

Os estados de Sine e Salum estiveram menos sujeitos à islamização que aqueles jalofos, ao longo do século XVI. Em narrativa destinada ao rei luso-espanhol Felipe II, em 1594, o cabo-verdiano André Almada escrevia que "fica no beira-mar destes Jalofos uma casta de negros a que chamam Barbacins, e são gentios, e não têm seita nenhuma de mouro" (Brásio, 1964: 256). Este argumento corrobora a delação de Francisco sobre a ausência de elementos islâmicos nas conversas que teve com Gaspar e Pedro. Por outro lado, dá relevo à religiosidade muçulmana de seus companheiros jalofos, cuja população, conforme Almada, "é a mais dificultosa em receber a fé de Jesus Cristo N. S. que todas as outras nações dos negros de Guiné, porque quase todos seguem a seita de Mafoma, ou muitas coisas dela, e são Mouros" (Brásio, 1964: 233). 0 estabelecimento de relações entre pessoas que respondiam a diferentes estruturas políticas, linguísticas e religiosas antes da escravização atlântica sugere o compartilhamento de projetos pessoais e coletivos marcados pela condição cativa e/ou subalterna, além de outras identidades possiveis. 
Contudo, entre os escravizados muçulmanos interessados em escapar para no norte da África, havia uma agenda de temas religiosos que permeava as discussões, empreendidas a partir da mobilidade geográfica possível no ambiente urbano lisboeta. Questões teológicas, como os dogmas católicos e as perspectivas muçulmanas sobre a natureza de Deus caminhavam ao lado de debates sobre as possibilidades de salvação da alma em ambas as religiões. Nos encontros dos mouriscos nas ruas de Lisboa, este assunto era pauta recorrente: Francisco dirigia-se "ao terreiro do paço onde se juntaria com outros mouriscos [que] Ihe diziam muitas vezes (...) que não há senão um só deus nos céus e que a lei de Mafamede é boa (...) para salvar sua alma nela". ${ }^{10} 0$ ambiente urbano favoreceu o compartilhamento de crenças e articulações de projetos.

A religião foi um dos vetores que permitiram a aproximação entre os sujeitos subjugados pela perseguição inquisitorial, principalmente quando outras esferas de identificação eram difusas. Tal foi o caso de Francisco Jalofo, morador da vila de Setúbal, arrolado no processo de Antônio Dacunha, "mourisco turco de nação". "' Antônio Dacunha desejava fugir para o norte da África e, para tanto, buscou auxílio de Francisco, possuidor de um barco que poderia levá-lo. Dacunha prometia a Francisco que, se o levasse em seu barco, "Ihe daria lá cavalo e terras". ${ }^{12}$ A eles, unir-se-iam outros mouriscos. Francisco aceitou a proposta e "sendo cristão batizado se apartou de nossa santa Fé católica e se tornou à seita de Mafamede". ${ }^{13}$

Porém, o dito Jalofo afirma ter se arrependido e, no dia programado para partir, alegou a seus companheiros que o tempo não estava bom para viajar, buscando retardar a travessia. 0 período de planejamento da viagem durou cerca de um ano, no qual Francisco alegou que "andou assim enganado para se ir para terra de mouros para lá ser mouro". ${ }^{14}$ Afirmou que Antônio, o turco, ensinou-Ihe orações, embora ele já soubesse outras. Contudo, Antônio foi capturado pela inquisição e, em seu depoimento, denunciou Francisco, que se disse enganado por Antônio e se mostrava arrependido. Manuseando habilmente os recursos que lhe estavam disponíveis, como a negação de ter feito qualquer juramento islâmico - profissão de fé - e dizendo-se arrependido, Francisco Jalofo da vila de Setúbal conseguiu apaziguar sua situação. No processo, os inquisidores afirmaram que, embora sua heresia incorresse em sentença de excomunhão, seu arrependimento e confissão o habilitavam à reconciliação. Ao término, Ihe foi imposto "cárcere e hábito penitencial pelo tempo que parecer aos inquisidores". ${ }^{15}$

Em comum, os muçulmanos jalofos em Portugal tiveram a passagem por Arguim, o batismo como passaporte para o mundo católico português e o ingresso em redes sociais formadas por muçulmanos e/ou nãomuçulmanos, que tinham afinidades linguísticas, religiosas ou eram provenientes de regiões próximas. Não obstante a diversidade de parcerias, as 
crenças islâmicas que professavam tiveram destaque em seus depoimentos. Antes de analisar tais crenças, passemos ao processo de instrução islâmica na África, que lhes permitiu acessar os saberes religiosos muçulmanos, que Ihes foram caros em suas redes sociais, em Portugal.

\section{ESCOLAS CORÂNICAS NA SENEGÂMBIA}

$\mathrm{F}$ rancisco Jalofo sabia orações muçulmanas; Domingos sabia ler, escrever e conhecia o Alcorão, "a lei de Mafamede"; Francisco Jalofo de Setúbal queria ir ao norte de África para voltar à prática islâmica. Como estes saberes e práticas, descritos em Portugal, foram acessados pelos jalofos? Quais processos permitiram a adesão ao Islã não apenas comunitária, como suposto por Boulègue e Levtzion, mas individual, expressa na prática sistemática, pessoal, voluntária e consciente da religiosidade islâmica? Como o Islã mobilizado em Portugal se desenvolveu na África? Acreditamos que a resposta esteja nas escolas corânicas.

Segundo André Almada, ao longo do rio Gâmbia havia "três casas principais grandes, como entre nós conventos, de grande religião e devoção entre eles, nas quais residem estes religiosos e os que aprendem para esse efeito" (Brásio, 1964: 275). Estes religiosos eram os bexerins, os mestres responsáveis pelo ensino nas daaras, as escolas corânicas. 0 primeiro centro localizava-se na costa atlântica; o segundo a 70 léguas ao interior, em Malor, e o terceiro a 50 léguas do segundo, em Sutuco. Essas aldeias haviam integrado o império do Mali até meados do século XVI, quando este entrou em decadência. Neste período, compreendiam unidades políticas mandingas relativamente autônomas, ainda que formalmente vinculadas ao governante do Mali. Sutuco era um importante entreposto comercial e, assim como Malor, dava lugar à prática de jejuns e abstinências. Nestas aldeias desenvolviam-se culturas escritas, realizavam-se grandes feiras, e a oração islâmica, a salat, era praticada várias vezes ao dia: "fazem suas salas para o Oriente postos os rostos, e antes de as fazerem lavam primeiro o traseiro e depois o rosto. Rezam juntos com uma vozaria alta como muitos clérigos em coro, e no cabo acabam com Ala Arabi, e Ala mimi" (Brásio, 1964: 275-276).

Nos séculos XVI e XVII, muçulmanos jalofos frequentavam um dos principais centros produtores e divulgadores de saberes muçulmanos na África Ocidental, localizado na mesquita de Timbuctu (Mota, 2016b). Lá se estudavam diversas disciplinas concernentes à formação clássica islâmica, como lógica, gramática, direito, sufismo, história, geografia, poética e outras. Aqueles que realizavam esta formação eram os grandes marabutos, que atuavam com juristas nas cortes dos governantes e instruíam novos religiosos, os bexerins, a quem cumpria a instrução das crianças nos saberes islâmicos, nas daaras (Mota, 2016a). Em 1606, o jesuíta Baltazar Barreira descrevia a existência de escolas e mesquitas no Gâmbia: "seguem a seita de 
Mafoma como os mais que atrás ficam, e têm mesquitas e escolas de ler e escrever, e muitos casizes, que levam esta peste a outros Reinos da banda do Sul" (Brásio, 1964: 166).

A circulação de pessoas Mandinga e Jalofo pelo Gâmbia é notória, como evidenciado pelo comerciante inglês Richard Jobson. Em Sutuco, Jobson (1999: 126) presenciou o desenvolvimento da educação islâmica nas escolas locais entre 1621 e 1622, quando apontou o espaço onde se utilizavam pranchas de madeira como suporte para a escrita, realizada com 0 auxílio de tinta preta produzida pelos próprios bexerins:

(...) eles têm certas casas redondas construídas abertas, e são espaçosas, à moda deles, onde eles ensinam os jovens, desta maneira: Todas as crianças do sexo masculino que prosseguem a partir destes Mary-buckes [i.e. marabutos] são ensinadas a escrever e a ler, e visto que não há papel entre eles, além do que os nossos ou outros levam na rota de comércio; e, portanto, é de estima, eles por seus livros têm um pequeno quadro liso, próprio para segurarem em suas mãos, no qual as lições das crianças são escritas com uma espécie de tinta preta que eles fazem, e a pena é de uma forma de um lápis.

Jobson descreveu a estrutura da escola e os materiais utilizados nos estudos. Ainda em Sutuco, o jesuíta Manuel Álvares (s.d.: 11-verso) afirmava que "aqui existe uma escola comum onde a leitura e a escrita são ensinadas" e complementa:

Têm suas mesquitas; e os bozes ou bexerins põem escolas de ler e escrever letra arábica, de que usam em suas nôminas, sendo algumas regras delas a maldita relíquia. 0 ofício destes é criar meninos, que venham depois a servir de ministros. Todos aprendem ao nosso modo, escrevendo as matérias por seus traslados de dia gozando da sua luz e de noite ao fogo. E assim é espantoso ver a multidão de fogueiras a que se assentam, lendo e repetindo as lições, com uma gritaria que é uma confusão ver os infernais discípulos. Estes pedem esmola pela manhã e à noite e disto se mantêm.

No estado do Niumi, também descrito na documentação como "reino da Barra", à margem norte do rio Gâmbia próximo à foz, o médico francês Michel de La Courbe (1913: 191) encontrou forte desenvolvimento de uma cultura escrita muçulmana. 0 francês afirmou, em 1685:

Seguem a lei maometana, da qual são mais conhecedores que os povos do Cabo Verde [a península], tendo escolas públicas, onde eles aprendem a ler em Árabe, que é a língua da religião deles e na qual o Alcorão está escrito. Eles enviam a esta escola suas crianças, durante a noite, e se lhes escuta ler cantando as lições do Alcorão, ou orações em Árabe, que são escritas sobre pequenas placas de madeira; não há entre eles quem não saiba escrever e as letras arábicas 
servem a eles também para escrever sua língua natural; quando eles começam qualquer obra, eles dizem esta palavra: bissimilaye, que quer dizer Em nome de Deus, que é o começo do Alcorão, e muitos entre eles observam sua lei muito exatamente, não bebem nem vinho nem brande, e jejuam durante o Ramadã ou quaresma, muito regularmente.

La Courbe evidencia a aljamia, uma vez que aponta a escrita do idioma mandinga no alfabeto árabe. 0 cronista destaca o comprometimento de muitas pessoas nesta região com os preceitos islâmicos, entre os quais as permissões (halal) e restrições (haram) no tocante a consumo de alimentos e bebidas alcoólicas. 0 exercício dos Cinco Pilares também é destacado: entre os ritos a que todo muçulmano deve se dedicar (1.Profissão de Fé, 2.Oração, 3.Esmola, 4.Jejum do Ramadã e 5.Peregrinação a Meca), La Courbe aponta o compromisso com a oração e jejum no mês do Ramadã. No tocante às escolas, demonstra a forma de aprendizagem e o estudo sobre madeira em detrimento de papel, cujo uso era restrito à escrita permanente.

A educação era realizada no alfabeto e idioma árabe, uma vez que "a religião e a lei que eles ensinam não são escritas na mesma língua que eles falam publicamente" (Jobson, 1999: 127). Era um aprendizado intenso, pois na formação religiosa muçulmana a recitação memorizada do Alcorão é condição para prosseguimento nos estudos (Ware, 2014: 54). Assim, a leitura e repetição de lições descritas por Álvares, La Courbe e Jobson buscavam a incorporação da revelação divina pelos novos aprendizes. Após a formação, a eles cumpriria a função de divulgar e expandir a palavra de Deus: estes aprendizes tornar-se-iam os sujeitos que possibilitaram que homens como Francisco Jalofo, Domingos e outros dessem continuidade à crença islâmica desenvolvida na África em meio à escravidão atlântica, vivida em Portugal.

\section{Práticas religiosas de muçulmanos JALOFOS NA INQUISIÇÃO PORTUGUESA}

$\mathrm{E}$ m 1553, Antônio Fernandes, muçulmano jalofo, era interrogado na inquisição de Lisboa. Ele estava em Portugal desde 1551, onde manteve sua crença, produto da formação religiosa recebida na África. Seu depoimento é elucidativo acerca do Islã na Senegâmbia na primeira metade do século XVI:

Perguntado [sobre] antes de ser vendido para Portugal como se chamava e em que seita vivia e se é retalhado [i.e. circuncidado] ${ }^{16}$ e que orações sabia, disse que em sua terra se chamava Amaçambat e que era da seita de Mafamede e que Mafamede na sua terra se chama Hamat e que era retalhado de pequeno e que bem Ihe lembra quando o retalharam e que sabia muitas orações de sua seita que the ensinaram em pequeno como que fazem aos meninos. ${ }^{17}$ 
Fernandes aponta o papel central da educação islâmica na instrução das crianças e destaca a presença das escrituras sagradas. Amaçambat foi instruído na religião islâmica através da narrativa corânica, uma vez que o nome Hamat expõe uma corruptela de Ahmad, o profeta Maomé anunciado por Jesus, no Alcorão, como se lê na sura As Fileiras $(61,6)$ : "E quando Jesus, o filho de Maria, disse: 'Ó filhos de Israel, sou o Mensageiro que Deus vos enviou. Corroboro tudo quanto está na Tora e anuncio a chegada de um Mensageiro que virá depois de mim, chamado Ahmad'". A presença da circuncisão e das orações cumpre fortalecer a evidência da religiosidade jalofa vinculada aos saberes islâmicos em vigência na África Ocidental.

Os inquisidores esforçavam-se para conduzir o interrogatório de modo a levar o réu a confessar o que se the aplicava. Neste esforço, demonstraram conhecer parte dos rituais islâmicos, sobretudo no que tange aos Cinco Pilares. Na condição de cativos, muitos escravizados encontravam-se impossibilitados de realizar peregrinações a Meca ou a santuários de substituição. Os outros pilares, contudo, encontravam-se em seu horizonte de possibilidades. Ao recolher o depoimento de Francisco Jalofo, em 1553, o agente do Santo Ofício conduzia o interrogatório:

E logo foi perguntado se depois que se tornou cristão além das orações que diz que dizia da seita de Mafamede se ele fez o cila e o algo doch que é o lavatório dos mouros e se jejua o jejum de Ramadã e se fez o Alacare se jurou juramentos de mouros para Alquiba. E se sabe de outras pessoas que fizeram isto que dissesse a verdade.

As perguntas do inquisidor incidem diretamente sobre a oração (Al-salat ou sala, tratada por cila nesta fonte), precedida pela ablução ou purificação ritual (Wudu), os lavatórios citados. Ao tratar de juramentos para Alquiba, o oficial do Santo Ofício explicita não saber exatamente do que se tratava, uma vez que o termo Alquiba ou Alquibla significa a direção da grande mesquita de Meca, ou seja, o rumo que os fiéis devem tomar no exercício de suas orações. 0 termo Alacar não é acompanhado de nenhuma explicação. Contudo, é possível tratar-se de variação do termo Araka ou Hasaka que, no idioma jalofo, equivale ao Zakat, palavra aplicada à esmola islâmica. ${ }^{18}$ Já o jejum do Ramadã é corretamente apresentado pelo inquisidor. Estes elementos estavam presentes na fé professada na Senegâmbia (Mota, 2016a: 289-314). Ao descrever a prática do jejum, por exemplo, Manuel Álvares explicava:

0 jejum é de um mês, começando com a lua nova e acabando com ela. Durante este tempo, não tomam nada em todo o dia; pondo-se o sol mandam pilar milho e dele fazem água, a qual bebem, comendo o cuscus, carne e o mais que têm; antes do canto do galo mandam fazer papas de milho com leite para estarem com mais força para o jejum (...) fazem suas rezas à noite em certo lugar que para isto escolhem mais acomodado, fazendo-lhe uma tabanca de paus que 
prendem para o sítio ficar mais fresco, no meio se edifica uma cozinha pequena capaz de três ou quatro pessoas; finalmente, segundo a oportunidade, escolhem o lugar para as tais cerimônias, que são contínuas, durando o tempo de sua quaresma, que acaba aparecendo a lua nova, a qual recebem com muita festa e celebram a sua páscoa com todas as músicas e banquetes (Álvares, s.d.: 12).

A indicação de Álvares sobre hábitos alimentares noturnos durante o Ramadã, na África, chamado quaresma pelo jesuíta, lança luz sobre a prática islâmica em Portugal e nos auxilia na compreensão do relato de Francisco, ao afirmar ao inquisidor que "depois que foi cristão nunca jejuou ao modo de mouro, nem fez lavatório, nem fez o cila, nem se alevantava de noite a comer como fazem os mouros quando jejuam nem nunca jurou juramento de mouro". ${ }^{19} \mathrm{O}$ termo mouro é uma atribuição portuguesa aos muçulmanos, atrelada à ocupação islâmica da península Ibérica por contingentes berberes (os mouros), cuja expulsão definitiva aconteceu apenas em 1492, com a conquista de Granada. No depoimento dos jalofos, o termo equivale a muçulmano, em detrimento de referir-se à procedência mauritana. Este sentido é notado na atribuição da condição de mourisco a Antônio Dacunha, "turco de nação", citado acima.

Os processados afirmam que aprenderam as práticas islâmicas em sua terra, remetendo ao ambiente institucionalizado da islamização através das daaras, na Senegâmbia, no início do século XVI. Francisco Jalofo confessou "que de noite quando acabava [a oração] dizia hala hulala mafamede Risarala que dizia Deus é grande e Mafamede seu mensageiro. E que essa oração sabia ele na sua terra e quando dizia a essa oração ela lhe par[ecia?] que era boa para sua alma" ${ }^{20} \mathrm{~A}$ profissão de fé compreendida como oração esteve presente em vários depoimentos. Tal constatação evidencia certa confusão diante de um dos pilares do Islã. Não obstante, as vozes dos processados e inquisidores por vezes se misturam, dificultando-nos a percepção de quem, de fato, operava a diferenciação. Francisco distinguiu estes pilares, ao estabelecer diferenças entre "oração de mouro" e "oração grande", a profissão de fé:

era verdade que quando se deitava na cama dizia oração de mouro. Uma que começa / cimila Avaman/Avaym. E é oração grande e que quando de noite acordava dizia Hala llala Mahame crelal que quer dizer Deus é Deus e Mafamede é seu [cri?]ado. E que também de noite e de dia dizia outra oração que começa com colma orya e assim dizia outras orações de mouros. ${ }^{21}$

Há processos nos quais aparecem orações, mas não é enfatizada a profissão de fé. Antônio Jalofo afirmou que, de fato, ele recitava orações muçulmanas, mas não praticava a ablução antes delas nem jejuava: "quando lhe vinha lembrar a Lei de sua terra de Mafamede a tinha por boa e rezava orações que sabia dela, dizendo bismila/ aramanse/ avaim. E assim outras orações e que esta oração é do Alcorão e que se não lavava nem fazia jejuns de 
mouros". ${ }^{22}$ Por outro lado, há depoimentos que referenciam orações, entre as quais aparece a profissão de fé, sem incorrer em qualquer distinção:

Rezava a oração de bismila/e dam suvula/e leyla lá hala mahoma laava que quer dizer Deus é Deus, Mafamede que rogasse a Deus por ele e que nestas orações rezava sempre e que antes que andasse com esta proposta de se ir para terra de mouros rezava as ditas orações de mouro por não saber outra nenhuma oração de cristão. ${ }^{23}$

Destacamos que as expressões "Hala llala Mahame crela", "hala hulala mafamede Risarala" e "leyla lá hala mahoma laava", resultado da transcrição da oralidade presente numa língua que os inquisidores desconheciam, possivelmente indicam apropriações/transcrições incompletas e/ou incorretas da fórmula "la 'ilaha 'illal-lah an Muhammadur rasulu llahi". Trata-se do primeiro dos Cinco Pilares, shahada ou profissão de fé, cujo reconhecimento é fundamental para a adesão do fiel às fileiras do Islã. Seu significado é "não há outra divindade além de Deus e Maomé é o seu profeta", análogo ao transcrito nos processos acerca dos ditos pronunciados e traduzidos pelos muçulmanos jalofos. Este rito implica a aceitação da unidade divina e do caráter profético atribuído a Maomé. É, portanto, o "juramento de mouro" buscado pelos inquisidores como pecha para condenação e renegado pelos inquiridos, manuseando habilmente as condições que lhes eram apresentadas no processo.

As expressões "bismila aramanse avaim" ou "cimila Avaman Avaym" são corruptelas de bismillah rahmani rahim: a fórmula "Em nome de Deus, o Clemente, o Misericordioso", presente em muitos textos muçulmanos, inclusive no A/corão, ensinada na África Ocidental, como discutimos acima. As diferenças na grafia decorrem de variações na pronúncia/forma como os termos foram entendidos pelos inquisidores. Ademais, na primeira expressão, a palavra bismila indica uso do idioma árabe, sendo que cimila indica a pronúncia do mesmo termo no idioma jalofo.

Tais práticas religiosas, desempenhadas pelos muçulmanos jalofos e descritas na documentação inquisitorial portuguesa, sugerem o alcance da instrução islâmica realizada na Senegâmbia, cuja continuidade se evidencia no Mundo Atlântico. Os saberes islâmicos acessados, produzidos e reproduzidos, na Senegâmbia e em Portugal, possibilitaram-lhes estabelecer redes sociais que superavam limites étnicos e políticos africanos, estigmas de cor e de condição social: através do Islã e dos saberes compartilhados, aliaram-se a "mouros brancos" e a muçulmanos turcos com o fito de escapar das imposições de ordem religiosa e social da sociedade escravista portuguesa. 0 Islã foi mobilizado como linguagem, cujas orações e ritos concernentes aos Cinco Pilares demonstram o sucesso da instrução anterior e a possibilidade oferecida por ela para a integração dos jalofos na Umma: a comunidade global muçulmana. 


\section{CONSIDERAÇÕES FINAIS}

partir desta análise, constatamos que o estudo da fé islâmica professada pelos jalo-
fos em Portugal necessita de abordagem que considere o contexto cultural do qual seus praticantes foram retirados. A despeito de parte da historiografia afirmar que o Islã na Senegâmbia tomou abrangência social apenas a partir do século XVIII, acreditamos que este processo tenha sido anterior. As escolas corânicas e os ritos e práticas dos muçulmanos jalofos processados pela Inquisição evidenciam tal interpretação. Notamos, portanto, que o desenvolvimento da instrução religiosa na África possibilitou a continuidade de crenças e práticas muçulmanas em Portugal. Os processos evidenciam elementos centrais da educação islâmica, como a leitura e escrita árabe, conhecimentos do Alcorão e dos ritos concernentes aos Cinco Pilares, amplamente praticados na Senegâmbia.

Estas conclusões partem do uso da metodologia atlântica, uma vez que o confronto entre fontes decorrentes de experiências europeias na África e da presença africana em Portugal possibilita novos arranjos dos dados disponíveis, contribuindo para a ampliação dos conhecimentos tanto sobre o Islã na África quanto sobre a escravidão africana em Portugal. Neste ínterim, concluímos que, na interação entre estas duas agendas de pesquisa, ambas se iluminam mutuamente, evidenciando elementos que a abordagem separada não é capaz de trazer ao debate devido à natureza fragmentada da documentação. A perspectiva atlântica mostra-se rica ferramenta para estudos do Islã na África Ocidental e na diáspora jalofa entre os séculos XVI e XVII. Seguimos neste desafio.

\section{NOTAS}

1 Utilizamos o termo jalofo conforme aparece nas fontes portuguesas. Equivale ao francês djolofe ao inglês wolof. Optamos pela grafia portuguesa pelo apelo fonético presente no termo, tal como ouvido e registrado na documentação. São etnônimos aos quais se aplica a mesma regra: fula, equivalente a peu/e pulo, mandinga, equivalente a mandinka e manding, serere, equivalente a serer.

2 Utilizamos o termo estado para identificar uma unidade política com graus relativos de autonomia, sem incorrer nas definições aplicáveis ao Estado moderno, no sentido europeu. Evitamos termos como reino ou império em situações nas quais a natureza da unidade política representada não esteja clara e/ou não seja equivalente. 0 Caior, por exemplo, foi uma unidade vinculada ao Jolof, com sede no interior, cujo grau de dependência não equivale ao sentido europeu atribuído a reino, como aplicado pela historiografia para descrever, entre outros, o reino do Congo.

3 Instituto dos Arquivos Nacionais/Torre do Tombo/Tribunal do Santo Ofício/Inquisição de Lisboa/028/processo 4031, fls. 5-6 (a partir de agora, IAN/TT/TSO/IL/028/processo). 
THIAGO HENRIQUE MOTA

4 Criada em meados do século anterior, é curioso que Arguim figure nos dados do projeto Slave Voyages - The Trans-Atlantic Slave Trade Database como porto de aquisição de escravizados em apenas uma viagem, entre 1690 e 1691, em navio sob bandeira dinamarquesa.

5 IAN/TT/TSO/IL/028/processo 10832, fl. 4 . 0 batismo na fortaleza cumpria determinação régia de 1516, que afirmava a necessidade de se batizarem os cativos nas embarcações ou no local de recolhimento, com vistas a se evitarem falecimentos sem o sacramento.

6 IAN/TT/TSO/IL/028/processo 10949, fl. 4.

7 IAN/TT/TSO/IL/028/processo 07565, fl.06.

8 IAN/TT/TSO/IL/028/processo 4031, fl.11.

9 IAN/TT/TSO/IL/028/processo 4031, fl.12.

10 IAN/TT/TSO/IL/028/processo 4031, fl.06.

11 IAN/TT/TSO/IL/028/processo 07565, fl.02.

12 IAN/TT/TSO/IL/028/processo 07565, fl.05.

13 IAN/TT/TSO/IL/028/processo 07565, fl.07.

14 IAN/TT/TSO/IL/028/processo 07565, fl.06.

15 IAN/TT/TSO/IL/028/processo 07565, fl. 07.

16 "Circuncidar: v. at. talhar o prepúcio por motivo religioso ou outro (...)"; " Circuncidado: p. pass. de circuncidar. Fanado, que tem o prepúcio talhado (...)" (Silva, 1789: p.399).

17 IAN/TT/TSO/IL/028/processo 10832, fl. 05.

18 Sou grato a Fatime Samb, Fanny Longa Romero, Domy Kara e a Maraba, que me auxiliaram na tradução destes e outros termos presentes nesta pesquisa. Contudo, as diferenças entre uma língua oral e sua escrita no século XVI e as transformações históricas do idioma isentam meus interlocutores de responsabilidade sobre erros de tradução. Caso haja, estes cabem somente a mim.

19 IAN/TT/TSO/IL/028/processo 4031, fl. 09.

20 IAN/TT/TSO/IL/028/processo 4031, fl. 06.

21 IAN/TT/TSO/IL/028/processo 4031, fls. 06, 09.

22 IAN/TT/TSO/IL/028/processo 10832, fl. 05.

23 IAN/TT/TSO/IL/028/processo 07565, fl.06.

\section{REFERÊNCIAS BIBLIOGRÂFICAS}

ÁLVARES, Manoel. Etiópia Menor e descrição geográfica da Província da Serra Leoa composta pelo Padre Manoel Alvares da Companhia de Jesus estando assistente na mesma Provincia da Serra Leoa que não concluiu nem pôs a limpo por causa do seu falecimento no ano de 1616. Copiada do próprio original que se 
conserva no Real Convento de São Francisco da Cidade de Lisboa. S. d. Manuscrito disponível na Sociedade de Geografia de Lisboa, Res.3 E-7.

BAILYN, Bernard. The ideia of Atlantic History. Itinerario, v. XX, n. 1, 1996.

BOULEGUE, Jean. Les Royaumes Wolof dans /'espace Sénégambien (XIIle-XVIIle siècle). Paris: Khartala. 2013.

BRÁSIO, Antônio (ed.). Monumenta Missionaria Africana. África Ocidental. Segunda Série, vol. III. Lisboa: Agência Geral do Ultramar. 1964.

CALAINHO, Daniela. Metrópole das Mandingas: religiosidade negra e inquisição portuguesa no Antigo Regime. Rio de Janeiro: Garamond, 2008.

CHAMBERS, Douglas. The Black Atlantic: theory, method, and practice. In: Toyin Falola/Kevin Roberts (eds.). The Atlantic World, 1450-2000. Bloomington and Indianapolis: Indiana.

DIOUF, Sylviane. Servants of Allah: African Muslims enslaved in the Americas. NewYork and London: New York University Press, 2013.

FARIA, Patrícia Souza de. De Goa a Lisboa: memórias de populações escravizadas do império asiático português (séculos XVI e XVII). Revista Ultramares,vol. 5, nº 9, 2016.

FONSECA, Jorge. A historiografia sobre os escravos em Portugal. Cultura - Revista de História e Teoria das Ideias, vol. 33, 2016.

GEERTZ, Clifford. Observando o Islä: o desenvolvimento religioso no Marrocos e na Indonésia. Rio de Janeiro: Jorge Zahar, 2004.

GILROY, Paul. O Atlântico Negro. Modernidade e dupla consciência. São Paulo/Rio de Janeiro: 34/Universidade Cândido Mendes - Centro de Estudos Afro-Asiáticos, 2001.

GINZBURG, Carlo. 0 inquisidor como antropólogo: uma analogia e as suas implicações. In: GINZBURG, C. A micro-história e outros ensaios. Rio de Janeiro: Bertrand, 1991.

GOMEZ, Michael A. Black crescente: the experience and legacy of African Muslims in the Americas. New York: Cambridge University Press, 2005.

GREEN, Toby. The rise of the Trans-Atlantic Slave Trade in Western Africa, 1300-1589. New York: Cambridge University Press, 2012.

HORTA, José da Silva. A Guiné do Cabo Verde: produção textual e representações (1578-1684). Lisboa: Fundação Calouste Gulbenkian/ Fundação para a Ciência e a Tecnologia, 2011.

JOBSON, Richard. The Golden Trade: or, A Discovery of the River Gambia. In: GAMBLE, David; HAIR, P. E. H. (orgs.). The Discovery of River Gambia by Richard Jobson. London: The Hakluyt Society, 1999.

LA COURBE, M. Premier voyage du Sieur de La Courbe fait à la coste d'Afrique en 1685. Cultru P. (ed.). Paris: Société de l'Historie des Colonies Françaises, 1913.

MAINGUENEAU, Dominique. Novas tendências em análise do discurso. Campinas, SP: Ed. da UNICAMP/ Pontes Editores, 1997.

MARCUSSI, Alexandre Almeida. Um pregador africano na inquisição portuguesa: Bento de Jesus e a ideologia da escravidão em Cabo Verde no século XVII. Odeere: revista do programa de pós-graduação em Relações Étnicas e Contemporaneidade - UESB. Ano 1, número 1, janeiro-junho de 2016. 
THIAGO HENRIQUE MOTA

MENDES, Antônio de Almeida. Portugal e o tráfico de escravos na primeira metade do século XVI. Africana Studia, n.7, 2004.

MOTA, Thiago Henrique. Portugueses e muçulmanos na Senegâmbia: história e representações do Islã na África (c. 1570-1625). Curitiba: Prismas, 2016 a.

"Sobre o Alcorão e por Maomé": Islã, produção intelectual e capital cultural na Senegâmbia (séculos XVI e XVII). In. REIS, R.; RESENDE, T.; MOTA, T.. Estudos sobre África Ocidental: dinâmicas culturais, diálogos atlânticos. Curitiba: Editora Prismas, 2016b.

REIS, João José. Rebelião escrava no Brasil: a história do levante dos Malês em 1835. 2a. ed. revista e ampliada. São Paulo: Companhia das Letras, 2003.

RIBAS, Rogério. Filhos de Mafoma: mouriscos, cripto-islamismo e inquisição no Portugal quinhentista. Tese (Doutorado em História Moderna - sociedades islâmicas). Universidade de Lisboa. Lisboa, 2005.

SANTOS, Vanicléia. Africans, Afro-Brazilians and Afro-Portuguese in the Iberian Inquisition in the seventeenth and eighteenth centuries. In: African and Black Diaspora: an International Journal, n.5, v.1, 2012.

SAUNDERS, A. C. História Social dos escravos e libertos negros em Portugal, (1441-1555), Lisboa: Imprensa Nacional - Casa da Moeda, 1982.

SILVA, Antonio de Moraes. Diccionario da lingua portugueza - recompilado dos vocabularios impressos ate agora, e nesta segunda edição novamente emendado e muito acrescentado. Lisboa: Typographia Lacerdina, 1789.

SILVA, Filipa R. A Inquisição em Cabo Verde, Guiné e S. Tomé e Principe (1536-1821): contributo para o estudo da política do Santo Ofício nos territórios africanos. Dissertação (Mestrado em História dos Descobrimentos e da Expansão Portuguesa). Universidade Nova de Lisboa. Lisboa. 2002.

Slave Voyages - The Trans-Atlantic Slave Trade Database, http://slavevoyages.org/, acesso em 22 de outubro de 2016.

SWEET, James. Recriar a África: cultura, parentesco e religião no mundo afro-português (1440-1770), Lisboa: Edições 70, 2007.

THORNTON, John. A África e os africanos na formação do mundo atlântico - 1400-1800. Trad. Marisa Rocha Mota. Rio de Janeiro: Elsevier, 2004.

TINHORÃO, J. R. Os negros em Portugal: uma presença silenciosa. Lisboa: Caminho, 1988.

WARE III, Rudolph T. The Walking Qur'an: Islamic Education, Embodied Knowledge, and History in West Africa. Chapel Hill: The University of North Carolina Press, 2014. 